Nevada

Environmental

Restoration

Project

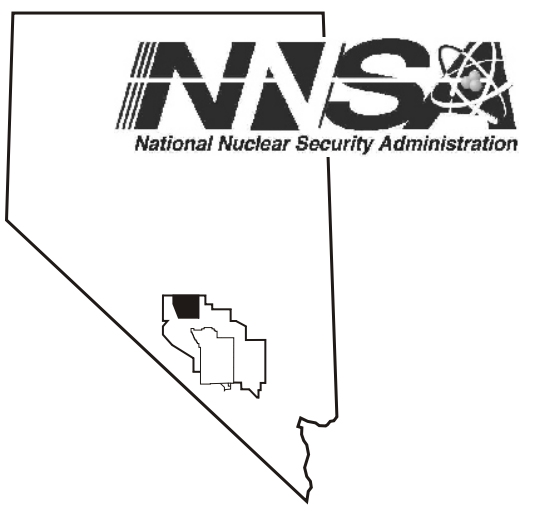

Streamlined Approach for

Environmental Restoration Plan for Corrective Action Unit 496: Buried Rocket Site, Antelope Lake,

Tonopah Test Range, Nevada

Controlled Copy No.:

Revision: 0

May 2004

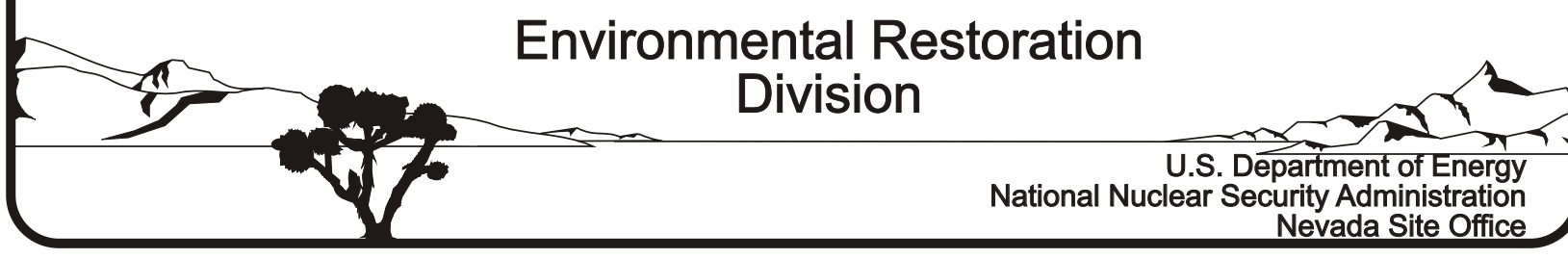




\section{Disclaimer Statement}

References herein to any specific commercial product, process, or service by trade name, trademark, manufacturer, or otherwise, does not necessarily constitute or imply its endorsement, recommendation, or favoring by the U.S. Government, or any agency thereof, or its contractors or subcontractors.

\section{Availability Statement}

Available for sale to the public from:

U.S. Department of Commerce

National Technical Information Service

5285 Port Royal Road

Springfield, VA 22161

Phone: 800.553.6847

Fax: 703.605.6900

Email: orders@ntis.gov

Online ordering: http://www.ntis.gov/ordering.htm

Available electronically at http://www.osti.gov/bridge

Available in paper form for a processing fee from the U.S. Department of Energy:

U.S. Department of Energy

Office of Scientific and Technical Information

P.O. Box 62

Oak Ridge, TN 37831-0062

Phone: 865.576 .8401

Fax: 865.576.5728

E-mail: reports@adonis.osti.gov 


\title{
STREAMLINED APPROACH FOR ENVIRONMENTAL RESTORATION PLAN FOR CORRECTIVE ACTION UNIT 496: BURIED ROCKET SITE, ANTELOPE LAKE, TONOPAH TEST RANGE, NEVADA
}

\author{
Prepared for: \\ U.S. Department of Energy \\ National Nuclear Security Administration \\ Nevada Site Office \\ Under Contract No. DE-AC08-96NV11718
}

Controlled Copy No.

Revision: 0

May 2004 
THIS PAGE INTENTIONALLY LEFT BLANK 


\section{STREAMLINED APPROACH FOR ENVIRONMENTAL RESTORATION PLAN FOR CORRECTIVE ACTION UNIT 496: BURIED ROCKET SITE, ANTELOPE LAKE, TONOPAH TEST RANGE, NEVADA}

Approved By: SIGNATURE APPROVED

Date: $\quad 4 / 28 / 04$

Kevin Cabble, Acting Project Manager

Industrial Sites Project

Approved By: $\frac{\text { SIGNATURE APPROVED }}{\text { Janet Appenzeller-Wing, Acting Division Director }}$

Date: $4 / 28 / 04$

Environmental Restoration Division 
THIS PAGE INTENTIONALLY LEFT BLANK 
ACRONYMS AND ABBREVIATIONS $\ldots \ldots \ldots \ldots \ldots \ldots \ldots \ldots \ldots \ldots \ldots \ldots$ vii

EXECUTIVE SUMMARY $\ldots \ldots \ldots \ldots \ldots \ldots \ldots \ldots \ldots \ldots \ldots \ldots \ldots \ldots \ldots$

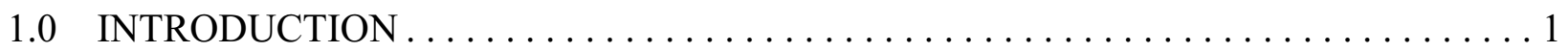

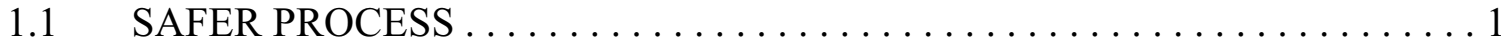

1.2 SUMMARY OF PROPOSED CORRECTIVE ACTION $\ldots \ldots \ldots \ldots \ldots \ldots \ldots 1$

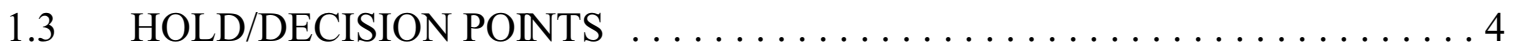

1.4 SAFER WORK PLAN CONTENTS $\ldots \ldots \ldots \ldots \ldots \ldots \ldots \ldots \ldots \ldots$

2.0 UNIT DESCRIPTION $\ldots \ldots \ldots \ldots \ldots \ldots \ldots \ldots \ldots \ldots \ldots \ldots \ldots \ldots \ldots \ldots$

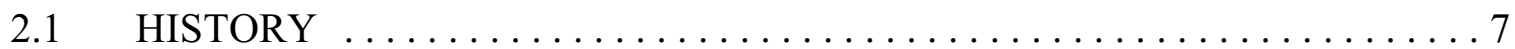

2.2 SITE LOCATION AND DESCRIPTION $\ldots \ldots \ldots \ldots \ldots \ldots \ldots \ldots \ldots$

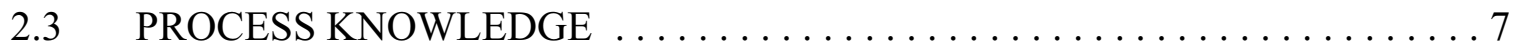

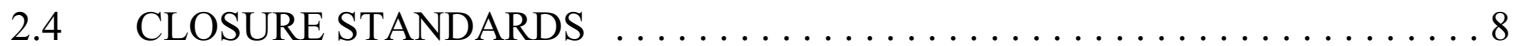

3.0 FIELD ACTIVITIES AND CLOSURE OBJECTIVES $\ldots \ldots \ldots \ldots \ldots \ldots \ldots \ldots \ldots \ldots$

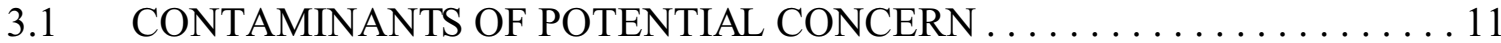

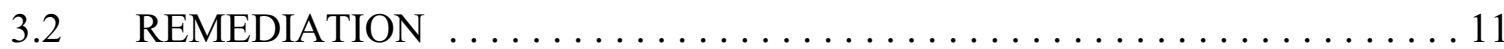

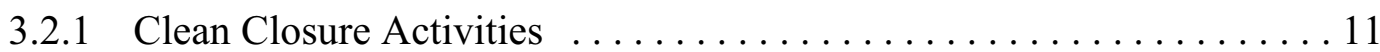

3.2 .2 No Further Action Activities . . . . . . . . . . . . . . . . . 12

3.2 .3 Closure In Place Activities . . . . . . . . . . . . . . . . . . . . . . . 12

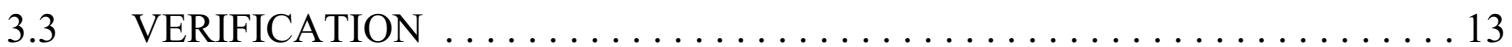

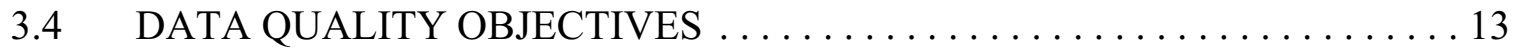

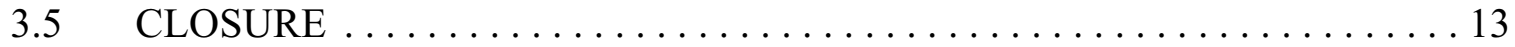

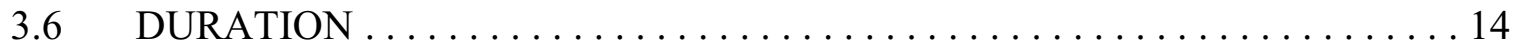

$4.0 \quad$ REPORTS AND RECORDS AVAILABILITY $\ldots \ldots \ldots \ldots \ldots \ldots \ldots \ldots \ldots \ldots$

5.0 INVESTIGATION/REMEDIATION WASTE MANAGEMENT . . . . . . . . . . . . . . . . . . . . . . . . . . . 19

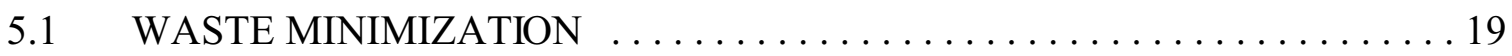

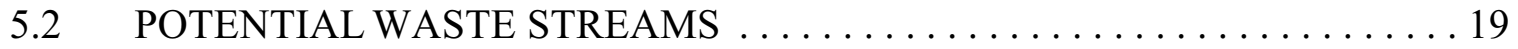

6.0 QUALITY ASSURANCE/QUALITY CONTROL $\ldots \ldots \ldots \ldots \ldots \ldots \ldots \ldots \ldots \ldots 21$

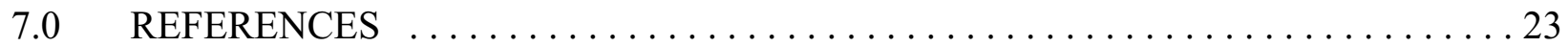




\section{TABLE OF CONTENTS (continued)}

\section{FIGURES}

FIGURE 1 - CAU 496 SITE LOCATION MAP $\ldots \ldots \ldots \ldots \ldots \ldots \ldots \ldots \ldots \ldots \ldots \ldots \ldots$

FIGURE 2 - CAS TA-55-008-TAAL, BURIED ROCKET, ANTELOPE LAKE $\ldots \ldots \ldots \ldots 3$

FIGURE 3 - CAU 496 PROPOSED SAFER CLOSURE PROCESS . . . . . . . . . . . . . . . 5

FIGURE 4 - CAU 496 SAFER FIELDWORK SCHEDULE $\ldots \ldots \ldots \ldots \ldots \ldots \ldots \ldots$

\section{APPENDICES}

APPENDIX A1 - DATA QUALITY OBJECTIVES

APPENDIX A2 - PROJECT ORGANIZATION

DISTRIBUTION LIST 


\begin{tabular}{|c|c|}
\hline \multicolumn{2}{|c|}{ ACRONYMS AND ABBREVIATIONS } \\
\hline$\overline{\mathrm{BN}}$ & Bechtel Nevada \\
\hline CAS & Corrective Action Site \\
\hline CAU & Corrective Action Unit \\
\hline $\mathrm{COC}$ & Contaminant(s) of concern \\
\hline $\mathrm{COPC}$ & Contaminant(s) of potential concern \\
\hline CR & Closure Report \\
\hline CSM & Conceptual Site Model \\
\hline DOE & U.S. Department of Energy \\
\hline $\mathrm{DOE} / \mathrm{NV}$ & U.S. Department of Energy, Nevada Operations Office \\
\hline DQO & Data Quality Objective \\
\hline DU & Depleted Uranium \\
\hline EOD & Explosive Ordnance Disposal \\
\hline EPA & U.S. Environmental Protection Agency \\
\hline EM & Electromagnetic \\
\hline FFACO & Federal Facility Agreement and Consent Order \\
\hline $\mathrm{ft}$ & foot (feet) \\
\hline GPS & Global positioning system \\
\hline $\mathrm{m}$ & $\operatorname{meter}(\mathrm{s})$ \\
\hline NDEP & Nevada Division of Environmental Protection \\
\hline NNSA/NSO & $\begin{array}{l}\text { U.S. Department of Energy, National Nuclear Security Administration Nevada } \\
\text { Site Office }\end{array}$ \\
\hline NNSA/NV & $\begin{array}{l}\text { U.S. Department of Energy, National Nuclear Security Administration Nevada } \\
\text { Operations Office }\end{array}$ \\
\hline NTS & Nevada Test Site \\
\hline PPE & personal protective equipment \\
\hline PRG & preliminary remediation goals \\
\hline QA & quality assurance \\
\hline QC & quality control \\
\hline RDGPS & real-time differential global positioning system \\
\hline RSL & Remote Sensing Laboratory \\
\hline SAFER & Streamlined Approach for Environmental Restoration \\
\hline TTR & Tonopah Test Range \\
\hline UXO & Unexploded Ordnance \\
\hline
\end{tabular}


SAFER PLAN - CAU 496

Section: Acronyms \& Abb.

Revision: 0

Date: May 2004

THIS PAGE INTENTIONALLY LEFT BLANK 
This Streamlined Approach for Environmental Restoration plan details the activities necessary to close Corrective Action Unit (CAU) 496: Buried Rocket Site, Antelope Lake, located at the Tonopah Test Range, Nevada. CAU 496 is currently listed in Appendix III of the Federal Facility Agreement and Consent Order (FFACO, 1996). CAU 496 consists of one Corrective Action Site (CAS):

- $\quad$ CAS TA-55-008-TAAL, Buried Rocket

The single CAS (TA-55-008-TAAL) consists of a potential rocket located either on the ground surface or in the shallow subsurface. There are no contaminants of potential concern anticipated for this CAS.

The closure of CAU 496 will be based on the results of reviewing historical documents, site visits, process knowledge, and/or results of the geophysical and multispectral surveys. If the rocket or conclusive evidence of the rocket is located, the site will either be clean-closed or closed in place. Any surface debris related to the rocket will be removed and disposed. Subsurface material located to a depth of 3 meters (10 feet) below ground surface will be excavated and disposed.

If no potential targets are identified that are determined to be related to CAU 496, the "no further action" alternative will be selected based on the approach previously approved by Nevada Division of Environmental Protection (NDEP) for CAU 495 (Unconfirmed JTA Sites [TTR]) (NDEP, 1999). This approach will allow closure of the unconfirmed site with no land/site use restrictions and no post-closure monitoring. However, if additional evidence becomes available in the future which indicates the location of the rocket, the site will be reopened to continue the investigation. 
SAFER PLAN - CAU 496

Section: Executive Summary

Revision: 0

Date: May 2004

\section{THIS PAGE INTENTIONALLY LEFT BLANK}




\subsection{INTRODUCTION}

This Streamlined Approach for Environmental Restoration (SAFER) plan details the activities necessary to close Corrective Action Unit (CAU) 496: Buried Rocket Site, Antelope Lake (TTR). CAU 496 consists of one site located at the Tonopah Test Range (TTR), Nevada (Figures 1 and 2), and is currently listed in Appendix III of the Federal Facility Agreement and Consent Order (FFACO, 1996). CAU 496 consists of one Corrective Action Site (CAS):

- $\quad$ CAS TA-55-008-TAAL, Buried Rocket

\subsection{SAFER PROCESS}

CAUs that may be closed using the SAFER process have conceptual corrective actions that are clearly identified. Consequently corrective action alternatives can be chosen prior to the completion of a corrective action investigation given anticipated investigation results.

The SAFER process combines elements of the data quality objectives (DQOs) process and the observational approach to help plan and conduct corrective actions. DQOs are u sed to identify a problem and define the type and quality of data needed to complete the investigation phase of the process. The purpose of the investigation phase in the SAFER process is to verify the adequacy of existing information to implement the corrective action. The observational approach provides a framework for managing uncertainty and planning decision making.

Using the SAFER process allows technical decisions to be made based on incomplete but sufficient information and the experience of the decision maker. Any uncertainties are addressed by documenting assumptions that are verified by sampling, analysis, data evaluation, and onsite observation as planned activities progress, and by contingency plans, as necessary. Remediation and closure may proceed simultaneously with site characterization as sufficient data are gathered to confirm or disprove the assumptions made in selecting the closure method. During the site closure if new information is developed that indicates the closure method should be revised, closure activities will be modified to implement the revised closure method.

\subsection{SUMMARY OF PROPOSED CORRECTIVE ACTION}

Drive-over geophysical and radiological survey methods will be used to identify the potential location of waste at CAU 496. Waste locations potentially related to CAU 496 will also be confirmed with detailed site visits and additional geophysical surveys, as needed.

If the presence of waste is confirmed, corrective action will consist of clean-closure by removal and disposal if technically feasible. There are no contaminants of potential concern (COPC) identified for CAU 496. Verification sampling is not planned for remediation of CAU 496.

If no potential targets are identified that are determined to be related CAU 496, the "no further action" alternative will be selected based on the approach previously approved by Nevada Division of Environmental Protection (NDEP) for CAU 495 (Unconfirmed JTA Sites [TTR]) (NDEP, 1999). This approach will allow closure of the unconfirmed site with no land/site use 

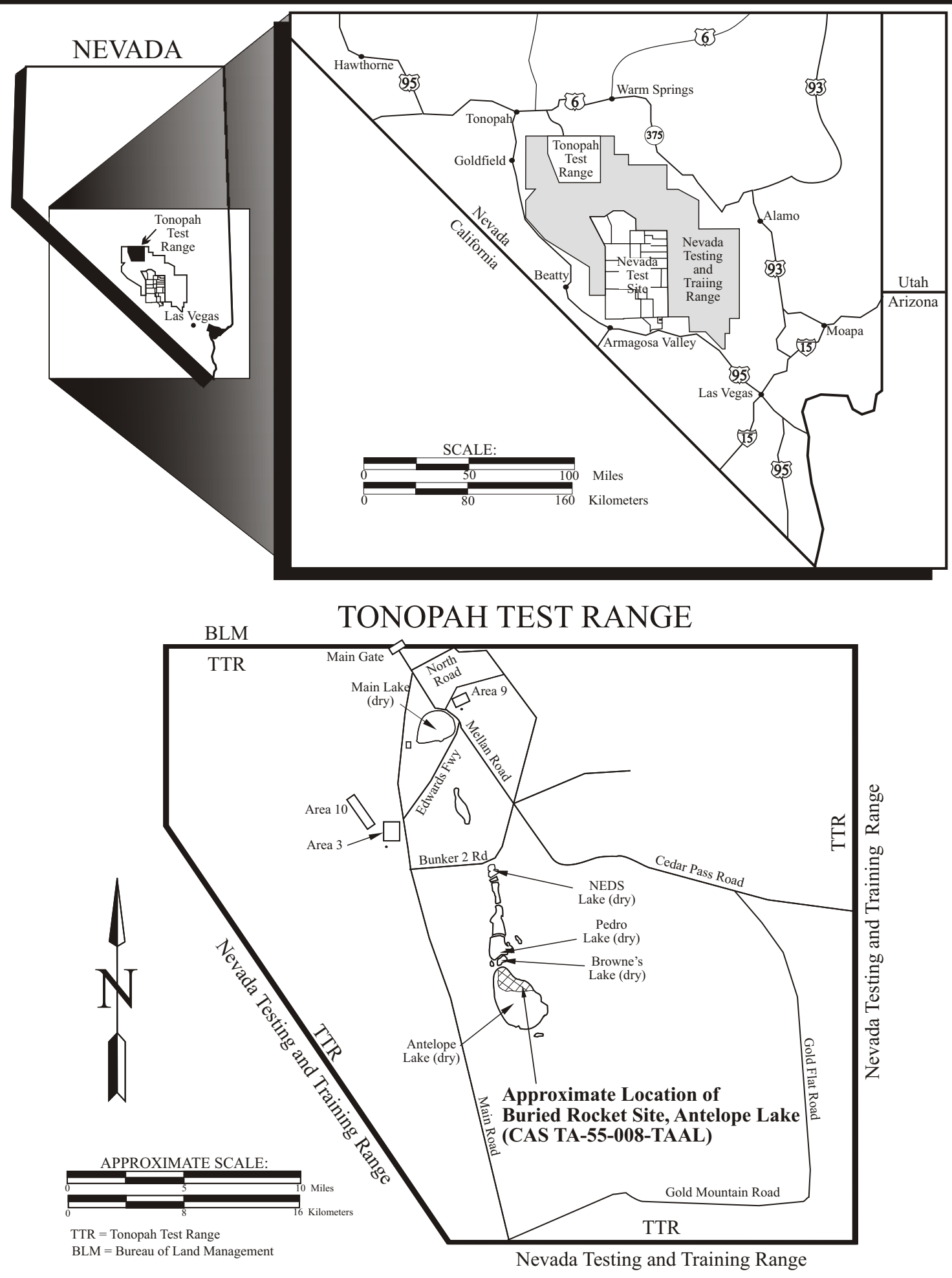

FIGURE 1

CAU 496 SITE LOCATION MAP 


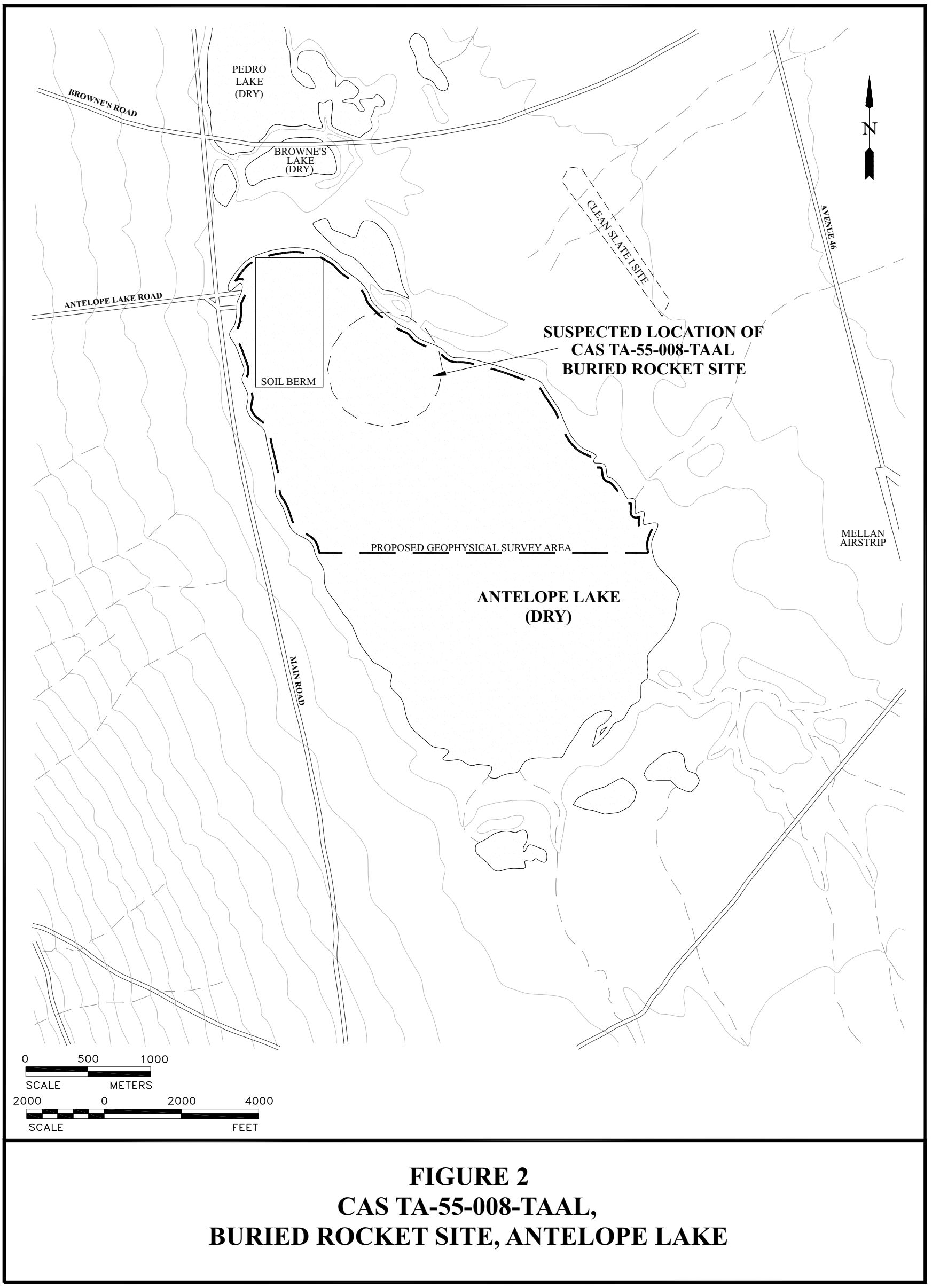


restrictions and no post-closure monitoring. However, if additional evidence becomes available in the future which indicates the location of the site, the site will be reopened to continue the investigation.

\subsection{HOLD/DECISION POINTS}

Geophysical data will be evaluated and potential targets will be identified. Potential targets and supporting data will be presented to U.S. Department of Energy, National Nuclear Security Administration Nevada Site Office (NNSA/NSO) for concurrence. Five potential scenarios have been identified for the buried rocket. If the rocket is located and is present in the shallow subsurface, the rocket may be recovered and the site clean closed. If the rocket is not located but fragments such as stabilizing fins are found on the surface or shallow subsurface, additional geophysical methods may be used to verify the depth of the rocket fuselage. If the rocket fuselage is greater than 3 meters $(\mathrm{m})$ (10 feet [ft]) below the ground surface, it will be closed in place with use restrictions. If evidence of the rocket is located off of Antelope Lake and the rocket is present on or near the ground surface (within $3 \mathrm{~m}[10 \mathrm{ft}]$ below ground surface), the debris will be removed and the site clean closed. If no targets are located during the investigation, the site will be closed with no further action using the CAU 495 precedent (NDEP, 1999). Findings will be presented to NNSA for concurrence prior to proceeding with additional investigation or closure activities. Presentation of collected data to NNSA will be hold points for the project. The general anticipated process for data gathering, evaluation, and hold/decision points is presented on Figure 3.

In addition to the previously discussed hold/decision points, work may be temporarily suspended until the issue can be satisfactorily resolved if any of the following unexpected conditions occur:

- $\quad$ Conditions outside the scope of work are encountered such as large amounts of unexploded ordnance,

- $\quad$ Radiological screening yields results which require an upgrade in procedures to continue survey work in specific areas,

- $\quad$ Elevated beryllium results for air samples collected for monitor worker breathing zone,

- $\quad$ Elevated levels of additional COPC not originally identified as being present at the site

- Unexpected conditions including additional waste and/or contamination,

- Detection of a contaminant of concern (COC) that would require re-evaluating a disposal pathway, such as with hazardous or low level waste,

- Unexpected unsafe conditions posing a threat to personnel, equipment, or the environment, not originally documented in the Site Specific Health and Safety Plan,

- $\quad$ Other technical factors requiring the preparation of a Record of Technical Change.

If any of these conditions occur, work will be paused and the NNSA/NSO and/or the NDEP will be notified. Work will resume when a resolution has been agreed upon and a Record of Technical Change, if required, has been approved by NNSA/NSO and NDEP. 


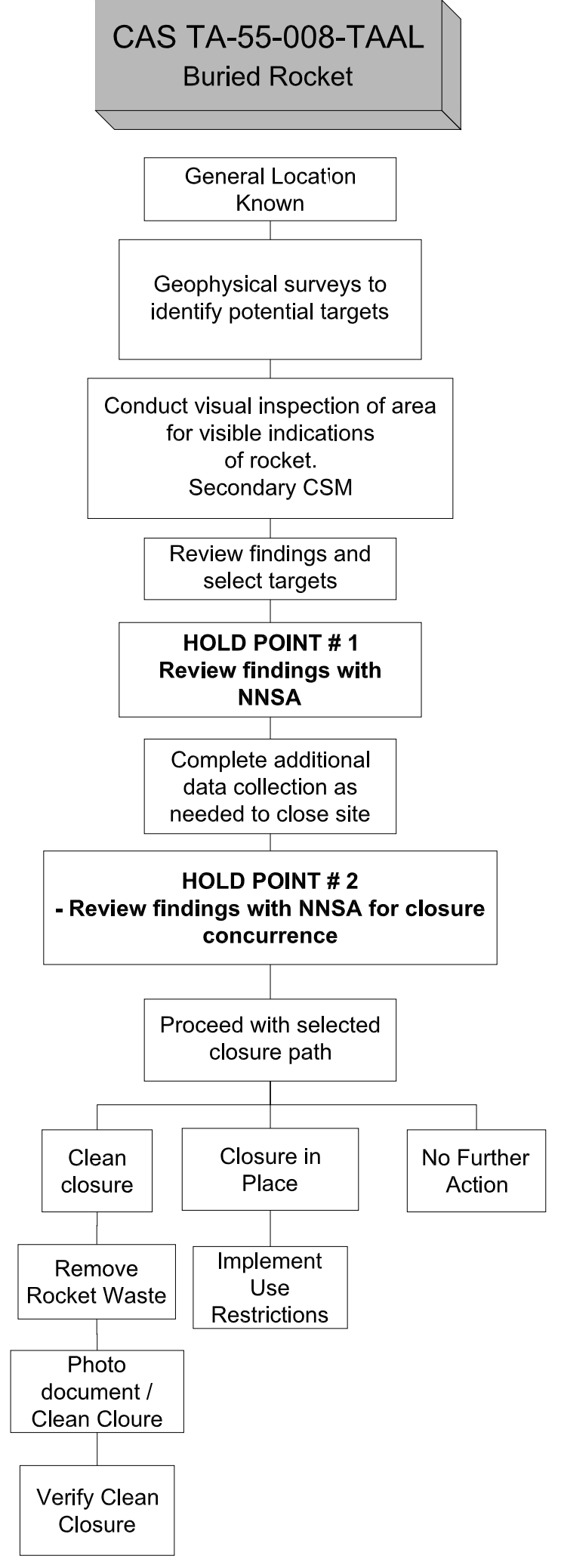

FIGURE 3

CAU 496 PROPOSED SAFER CLOSURE PROCESS 


\subsection{SAFER WORK PLAN CONTENTS}

This SAFER Work Plan has been developed to support the closure of CAU 496 according to the required FFACO format, including the following content by section:

- $\quad$ Section 1.0 - Introduction

- $\quad$ Section 2.0 - Unit Description

- $\quad$ Section 3.0 - Field Activities and Closure Objectives

- $\quad$ Section 4.0 - Reports and Records Availability

- $\quad$ Section 5.0 - Investigation/Remediation Waste Management

- $\quad$ Section 6.0 - Quality Assurance/Quality Control

- $\quad$ Section 7.0 - References

- $\quad$ Appendix A1 - Data Quality Objectives

- $\quad$ Appendix A2 - Project Organization

- Distribution List

This SAFER plan was developed using guidance provided from the following documents:

- $\quad$ Federal Facility Agreement and Consent Order (FFACO, 1996).

- Industrial Sites Quality Assurance Project Plan, (U.S. Department of Energy, National Nuclear Security Administration Nevada Operations Office [NNSA/NV], 2002). 


\subsection{UNIT DESCRIPTION}

CAU 496 consists of one CAS located at the TTR, Nevada (Figure 1). The majority of TTR, including Antelope Lake, is located in Cactus Flat. Cactus Flat is an intermontane basin, typical of the Basin and Range Physiographic Province, surrounded by the Cactus Range to the southwest, the northern portion of Kawich Range to the east, and the Monitor Range to the north. Cactus Flat is made up of Quarternary-aged alluvium eroded from the surrounding volcanic highlands. The alluvium can be divided into local landslide and talus, fan alluvium, valley-filled alluvium, and lake and shoreline deposits; each division differs in grain size, locality, and/or degree of compaction and cementation (United States Geological Survey, 1971).

\subsection{HISTORY}

CAS TA-55-008-TAAL, Buried Rocket, consists of a possible buried rocket or rocket parts from an undetermined test. The CAS was designated based on one former employee's memory of a rocket that fell on Antelope Lake in the 1960s. A general location for the rocket was obtained from the employee. However, there are numerous conflicting accounts regarding a missing rocket at TTR.

If a rocket was lost on Antelope Lake the rocket or parts of the rocket may be buried at depth or may have refracted up towards or onto the surface of the playa. There are no COPC expected to be associated with this site.

\subsection{SITE LOCATION AND DESCRIPTION}

According to historical documentation including interviews with former TTR employees, the rocket was apparently lost on the northeastern portion of Antelope Lake. Possible locations of CAS TA-55-008-TAAL will be identified during the field activities based on ground disturbances and the geophysical surveys.

\subsection{PROCESS KNOWLEDGE}

Although historical information about CAS TA-55-008-TAAL is limited, the site is believed to have originated during an undetermined test in the 1960s. There has been no direct documentation found that discusses the source or activities related to the buried rocket site; however, several potential test activities related to the buried rocket are discussed in available documentation and include the Flame test, Tomahawk test, Rebel test, Pershing II test, and the Earth Penetrator test. No direct correlation is made between these tests and the buried rocket. Interviews with current TTR personnel indicate no direct knowledge of the buried rocket or related events. It was mentioned that several rockets have misfired during testing and the rocket associated with CAU 496 could be present in a different location at TTR or the event could have been confused with a lost Davis Gun Penetrator (CAU 484 CAS RG-52-007-TAML). The buried rocket CAS was apparently added to the FFACO based on one interview which stated a rocket was buried in north Antelope Lake and had been marked with a four-inch by four-inch wood marker. This interviewee also indicated the approximate location of the buried rocket on a map. The location indicated by the interviewee correlates to an area of apparent ground 
disturbance on the northeast area of Antelope Lake which may or may not be related to the buried rocket. Additional interviews have suggested the buried rocket site may have been confused with a test associated with the Davis Gun Penetrator.

Three potential scenarios are possible for this site and are presented as the conceptual site model (CSM) and alternate CSMs for CAU 496 (Appendix A1). If a projectile (rocket) enters the ground surface at a steep angle (approaching 90 degrees from horizontal) the projectile will travel vertically to a depth determined by the design of the projectile, the velocity of the projectile, and the properties of the geologic material. A projectile that enters the ground surface at a shallow or acute angle will either maintain its momentum within the ground, it may refract and change direction within the ground but remain within the subsurface, or it may refract within the subsurface and travel back toward or even onto the ground surface. All potential scenarios presented within the CSMs for this site will be evaluated during the SAFER investigation.

\subsection{CLOSURE STANDARDS}

No COPC are associated with this CAS. The presence of waste associated with the rocket will be based on the results of reviewing historical documents, site visits, process knowledge, and results of the geophysical and multispectral surveys. If the rocket is located or conclusive evidence of the rocket is found, the site will either be clean-closed or closed in place. Any surface debris relating to the rocket will be removed and disposed. Subsurface material located to a depth of $3 \mathrm{~m}(10 \mathrm{ft})$ below ground surface will be excavated and disposed. Due to technological limitations of the survey equipment, items buried deeper than $3 \mathrm{~m} \mathrm{(10} \mathrm{ft)} \mathrm{below}$ grade will likely not be detected. No information has been identified to indicate hazards associated with the buried rocket. However, if unknown hazards do exist and the rocket is present at a depth of greater than $3 \mathrm{~m}(10 \mathrm{ft})$, the area would be considered suitable for unrestricted use according to current U.S. Department of Defense standards (DoD, 1999).

If no potential surface or subsurface targets are identified as CAS TA-55-008-TAAL, the "no further action" alternative will be requested based on the approach previously approved by NDEP for CAU 495 (Unconfirmed JTA Sites [TTR]), (NDEP, 1999). This approach will allow closure of the unconfirmed site with no land/site use restrictions and no post-closure monitoring. However, if additional evidence becomes available in the future which indicates the location of the site, the site will be reopened to continue the investigation. 


\subsection{FIELD ACTIVITIES AND CLOSURE OBJECTIVES}

This section provides the framework and rationale for characterization, removal, closure verification, site restoration, and waste disposal. The SAFER process is discussed in detail in the following subsections.

Prior to beginning the corrective action investigation and site closure fieldwork, the following activities will have been completed:

- Geophysical and radiological drive-over survey of the subject area

- $\quad$ Review and selection of potential site targets

- Development of an endangered species survey

- $\quad$ Preparation of National Environmental Policy Act documentation

- $\quad$ Preparation of a Site-Specific Health \& Safety Plan

- Cultural Resource Survey

- $\quad$ Preparation of an NNSA/NSO Real Estate/Operations Permit

Aerial Photography and Multispectral Survey

An aerial photography and multispectral survey was flown by the NNSA/NSO Remote Sensing Laboratory (RSL) in September 2003. The focus of this effort was to gather detailed

photography and multispectral data of areas where testing activities were reported to have been conducted but could not be concisely verified by site visits. The data were collected for Antelope Lake, Brownes Lake, Pedro Lake, NEDS Lake, and Mellan Hill. A multispectral survey collects data related to the reflectivity of materials on the ground surface. Multispectral data have been successfully used to identify areas of anthropological influence (e.g., disturbed ground, excavations, vehicle paths, etc). Multispectral imagery may also be used to identify the differences in natural geologic materials. In many cases, historical features not visible in natural-light photography are clearly visible in multispectral imagery. Multispectral imagery will be utilized during the review and interpretation of geophysical and radiological survey results to assist in identification of potential target areas for more detailed field investigation.

$\underline{\text { Radiologic al, Unexploded Ordnance (UXO), and Geophysical Surveys }}$

Radiological surveys will be conducted on Antelope Lake to map the surface and shallow subsurface distribution of radioactive debris to support the corrective action investigation and remediation of CAU 496. The purpose of these initial radiological surveys is to obtain preliminary information from which the scope and scale of the corrective action investigation and remediation program may be established. The objective of the radiological program is to map areas with elevated gamma activity due to meta-stable protactinium-234 (depleted uranium [DU] daughter product) or other gamma-emitting radionuclides. Targets located from these surveys will be examined in further detail during the corrective action investigation.

The radiological survey will consist of ground-based measurements using the RSL's specially modified Ford F-350 pickup truck equipped with the Radiation and Environmental Data Acquisition and Recorder system (Kiwi). The Kiwi system will collect the radiation data at a speed of approximately 10 miles per hour, at 71 centimeters ( 28 inches) above the ground, and with nominal line spacing of $3 \mathrm{~m}(10 \mathrm{ft})$. The metal detector survey will be conducted at the 
same time as the radiometric survey in order to minimize positioning errors and to maintain a complimentary data set. Radiological survey data may be used to identify areas with anomalous radioactive characteristics. This may be useful for CAU 496 in identifying areas of disturbed earth where geologic material with higher natural background has been brought to the surface and mixed with material with a lower background.

Position information is provided by a real-time differential global positioning system (RDGPS). Latitude and longitude coordinates are recorded second by second for post-survey analysis. Ideally, the vehicle operator is guided along the desired survey paths in real time by meter/lightbar indicators, driven by the RDGPS, which provide visual indications of vehicle deviation from the desired survey path. The RDGPS nominal accuracy is better than $1 \mathrm{~m}(0.3 \mathrm{ft})$ for both recorded and steering information. Under some circumstances, where straight line navigation is impossible (washes, rocks, bushes, and other obstacles), the vehicle operator may need to visually follow the vehicle path utilizing previous tire tracks to guarantee full areal coverage of the area of interest. The actual recorded path, not the planned path, is used for final data analysis.

The UXO assessment will be performed by an explosive ordnance disposal (EOD) technician to screen for potential UXO within the study area. The work scope requires that a certified EOD technician screen this area for potential UXO prior to the radiological/geophysical survey of the lake bed. The ordnance survey will be conducted from a vehicle and will be limited to visual observation of surface material, flagging and marking the location of any known or suspicious items. Global positioning system (GPS) coordinates of surveyed areas permissible for geophysical access will be marked on a plan map on a daily basis. GPS coordinates of known or suspicious objects will be reported daily and presented at the daily safety meeting prior to start of the work.

The electromagnetic (EM) survey will be conducted using a towed array time-domain metal detector system and a GPS system to map surface and shallow subsurface metallic debris. The practical limitations of the EM survey equipment define the shallow subsurface as the ground surface to an approximate depth of $3 \mathrm{~m}(10 \mathrm{ft})$ below ground surface. GPS data will be collected and integrated with the data collected by the radiological survey (Kiwi) system and metal detector system to produce a contour map of distributions of gamma-emitting radionuclides and metallic debris. Data will be collected along traverses with a line separation of ap proximately $3 \mathrm{~m}(10 \mathrm{ft})$ for approximately 95 percent coverage of the study area.

The EM survey will be conducted concurrently with the radiometric Kiwi survey in order to minimize positioning errors, maintain a complimentary data set, and reduce redundancy and project cost. The EM system will consist of three Geonics EM-61 MK2 high power time domain metal detectors. The detector coils will be operated as a time-synchronized array and will record four time gates of data per coil. The array will be tow ed behind the Kiwi system with a coverage width of approximately $3 \mathrm{~m}(10 \mathrm{ft})$, with the coils oriented for maximum spatial coverage.

\section{Data Integration and Utilization}

Drive-over radiological survey data, geophysical survey data, aerial photography, and multispectral imagery will be compiled and reviewed to support the corrective action 
investigation and remediation activities. The compiled data will be used to identify potential targets within the shallow subsurface within the study area.

It should be noted that conducting surveys over such a large area with an approximately 50 -year history of testing activity may identify multiple sites of interest that are not related to the sites included in CAU 496. While it is unknown how many targets will be identified during the drive-over surveys, if any, only those sites that most likely represent the CAS in CAU 496 will be targeted for further evaluation.

\subsection{CONTAMINANTS OF POTENTIAL CONCERN}

Based on site process knowledge and historical information, there are no known COPC associated with CAU 496.

\subsection{REMEDIATION}

\subsubsection{Clean Closure Activities}

Based on the background information, any waste associated with CAU 496 that may be detected will either be located on the ground surface or buried in the shallow subsurface (less than $3 \mathrm{~m}$ $[10 \mathrm{ft}]$ below ground surface).

Confirming the Presence of Waste Associated with the Rocket

The potential presence of waste associated with the missing rocket will be confirmed during the field activities. The presence of waste will be identified during the geophysical drive-over surveys and may be verified using portable instruments. Radiological data will be collected along with the geophysical surveys to be completed in support of CAU 484 (Surface Debris, Waste Sites, and Burn Area) SAFER activities. Surveys for CAU 484 are being performed concurrently with the surveys for CAU 496.

If no targets are identified within the study area the scope will be increased to complete a visual survey of the surrounding area for visible evidence of rocket debris. These surveys will include the inspection of aerial photography and site reconnaissance of the area. Additional research will be completed to determine if radar flight tracks are available from Sandia National Laboratories that could be related to the buried rocket.

Electromagnetic surveys will be used to determine the presence and lateral extent of areas containing surface or near-surface metallic objects/debris. The initial geophysical method used to define target CAS locations will be an EM-61 metal detector; however, additional geophysical methods may be used as needed to better refine the target CAS boundary and/or location.

Although radioactive materials are not expected, radiological surveys being performed concurrently for CAU 484 SAFER activities will include the suspected location of the buried rocket. Radiological survey data may also be useful in identifying areas of disturbed ground that could be associated with a buried rocket. 
Based on site conditions and available data, a portable magnetometer may be used to confirm the presence of waste prior to removal.

\section{Excavate Rocket Materials}

If a target area for the site is identified, any rocket debris removed from the site will be screened for radioactivity above free-release criteria (DOE/NV, 2000). The work area will be visually inspected for staining that could indicate the presence of COPC and/or areas of environmental impact. As there are no presumed COPC related to the site, sampling will not be performed unless field observations indicate potential COC impact of the surrounding material.

\section{Removal of Surface Rocket Debris}

If debris related to the rocket is located on the ground surface, the debris will be screened for radioactivity above free release criteria. The work area will be visually inspected for staining that could indicate the presence of COPC and/or areas of environmental impact. As there are no presumed COPC related to the site, sampling will not be performed unless field observations indicate potential COC impact of the surrounding material.

\section{Disposal of Rocket Materials}

If rocket components are removed and are not impacted, they will be screened as potential UXO and additional hazards such as residual fuel. After screening, the materials will be disposed of as solid waste and/or recycled if possible.

\section{Regrading/Backfilling Excavation with Clean Fill}

After removal of rocket components, the excavation will be backfilled using a front-end loader or equivalent equipment or by hand, depending upon the excavation depth/size. If necessary, water will be applied onto the fill material during the backfill activity to reduce dust and promote compaction. The excavated area will be backfilled to the approximate surrounding grade with the excavated soils. If required, additional soil will be used as backfill.

\subsubsection{No Further Action Activities}

For this closure option, the above described geophysical and radiological surveys will be performed in an attempt to locate the buried rocket. However, if no potential targets are identified as CAS TA-55-008-TAAL, the "no further action" alternative will be selected based on the approach previously approved by NDEP for CAS 495 (Unconfirmed JTA Sites [TTR]) (NDEP, 1999). This approach will allow closure of the unconfirmed site with no land/site use restrictions and no post-closure monitoring. However, if additional evidence becomes available in the future which indicates the location of the site, the site will be reopened to continue the investigation.

\subsubsection{Closure In Place Activities}

For this closure option, the above described geophysical and radiological surveys will be performed in an attempt to locate the buried rocket. If survey results indicate the rocket is present at a depth greater than $3 \mathrm{~m} \mathrm{(10} \mathrm{ft)} \mathrm{below} \mathrm{groung} \mathrm{surface,} \mathrm{the} \mathrm{site} \mathrm{will} \mathrm{be} \mathrm{closed} \mathrm{in} \mathrm{place}$ and use restrictions implemented. The coordinates for the rocket will be determined, and the information included in the CAU 496 Closure Report (CR). 


\subsection{VERIFICATION}

As no COPC are expected to be associated with CAU 496, no verification samples will be collected. If material is removed, clean closure will be visually verified and documented with site photographs.

\subsection{DATA QUALITY OBJECTIVES}

DQOs are qualitative and quantitative statements that specify the quality of the data required to support potential closure alternatives for CAU 496. The DQOs were developed to clearly define the purposes for which environmental data will be used and to design a data-collection program that will satisfy these purposes. The formulation of CSMs is an aid to the development of DQOs for the site.

During the DQO discussions for CAU 496, data needed to resolve problem statements and decision statements were identified. Criteria for data collection and analysis were defined and agreed upon, and the appropriate quality assurance (QA)/quality control (QC) required for particular data collection activities was assigned. Details of the DQO process are presented in Appendix A1.

\subsection{CLOSURE}

The specific closure activities proposed for CAU 496 are described in Section 3.2. Hold points and conditions that are outside the assumptions of this plan may impact the requirements for closure. If the buried rocket and/or components are located, the proposed activities for clean-closure of CAU 496 will consist of the following:

- $\quad$ Rocket components (which may include metal, ceramics, plastics, or wiring) related to CAU 496 will be identified and removed from the ground surface and/or excavated if necessary. All removed material will be screened as UXO before disposal as metal debris or recycled.

- $\quad$ All excavations will be backfilled with the excavated soils and augmented with soil from the TTR borrow pit, if necessary, and regraded to the surrounding to pography.

- $\quad$ A CR will be prepared and submitted to the NDEP for approval.

If no potential targets are identified as CAS TA-55-008-TAAL, the "no futher action" alternative will be selected based on the approach previously approved by NDEP for CAS 495 (Unconfirmed JTA Sites [TTR]) (NDEP, 1999). This approach will allow closure of the unconfirmed site with no land/site use restrictions and no post-closure monitoring. However, if additional evidence becomes available in the future which indicates the location of the site, the site will be reopened to continue the investigation. 
If the buried rocket and/or components are located at a depth of greater than $3 \mathrm{~m}(10 \mathrm{ft})$, the site will be closed in place and use restrictions implemented.

\subsection{DURATION}

The schedule will require modifications if conditions exist that are outside the assumptions on which the schedule was developed. Flexibility has been placed in the project schedule to account for minor difficulties (e.g., weather, equipment breakdowns, personnel availability, TTR operational and security constraints). NNSA/NSO will keep the NDEP informed of any condition that may impact the project schedule. Figure 4 presents the proposed project schedule following submittal of the final SAFER Plan for CAU 496. 


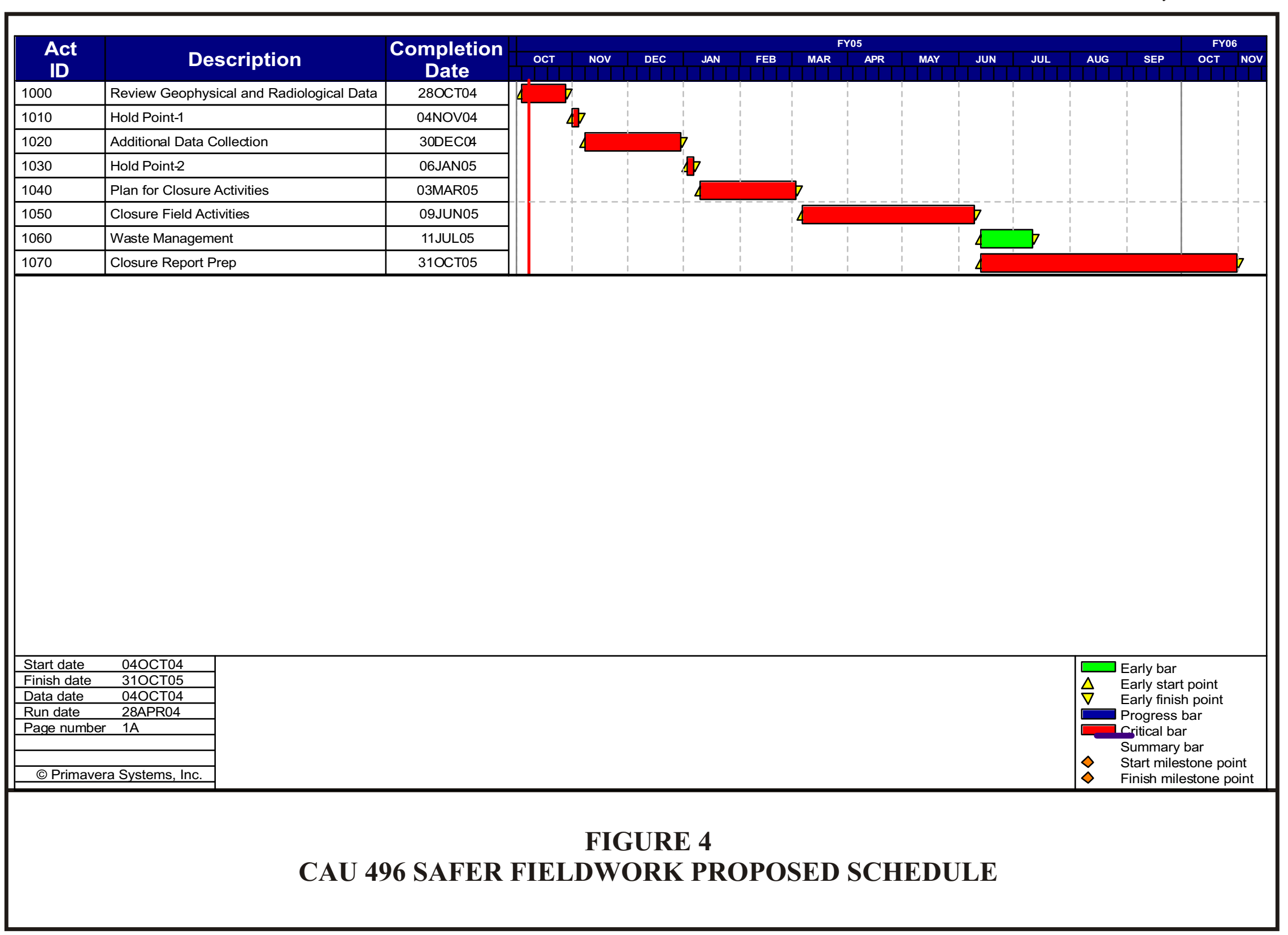


SAFER PLAN - CAU 496

Section: Field Acti vities

Revision: 0

Date: May 2004

\section{THIS PAGE INTENTIONALLY LEFT BLANK}




\subsection{REPORTS AND RECORDS AVAILABILITY}

A daily report will be prepared when field activities have started. The report will summarize the daily activities, site visitors, health and safety issues, and any other relevant issues or problems. This report will be provided to the NNSA/NSO Task Manager for submittal to the NDEP.

Upon completion of closure activities, a CR will be prepared and will include the following sections and subsections:

- $\quad$ Introduction (Purpose and Scope)

- Closure Activities (Description of Corrective Action Activities, Deviation from the SAFER Plan as Approved, Corrective Action Schedule as Completed, and Site Plan/Survey Plan)

- Waste Disposition

- $\quad$ Closure Verification Results (Data Quality Assessment and Use Restrictions)

- $\quad$ Conclusions and Recommendations

- $\quad$ References

- Supporting Documentation (Analytical Results for Verification Samples, Summary of Geophysical/Radiological Survey Results, Waste Disposition Documentation, and Modifications to the SAFER Plan)

The final CR will be submitted to NNSA/NSO and NDEP for review and approval. This document will be available in the NNSA/NSO Public Reading Facilities in Las Vegas, Nevada and Carson City, Nevada, or by contracting the NNSA/NSO Project Manager. The NDEP maintains the official administrative record for all activities conducted under the auspices of the FFACO (FFACO, 1996). 
SAFER PLAN - CAU 496

Section: Reports \& Rec.

Revision: 0

Date: May 2004

\section{THIS PAGE INTENTIONALLY LEFT BLANK}




\subsection{INVESTIGATION/REMEDIATION WASTE MANAGEMENT}

Waste from CAU 496 will be managed in accordance with all state and federal regulations, DOE orders, and Bechtel Nevada $(\mathrm{BN})$ procedures. Waste types are anticipated to consist entirely of non-hazardous waste.

\subsection{WASTE MINIMIZATION}

Waste generation will be minimized for the duration of the project by site workers adhering to the principles of the BN Waste Minimization and Pollution Prevention Program. Care will be taken to segregate waste from non-waste materials when possible and to avoid cross-contamination of waste streams.

\subsection{POTENTIAL WASTE STREAMS}

The potential waste stream generated by CAU 496 is anticipated to consist of non-hazardous debris which may include metal fragments, ceramics, plastics, wiring, and other debris related to the rocket. Additionally, used personal protective equipment (PPE) may be generated if closure activities are performed. Non-recyclable materials will be disposed as sanitary waste.

No waste will be generated if the CAS is not located and "no futher action" is requested. 
SAFER PLAN - CAU 496

Section: Waste Management

Revision: 0

Date: May 2004

\section{THIS PAGE INTENTIONALLY LEFT BLANK}




\subsection{QUALITY ASSURANCE/QUALITY CONTROL}

As there are no COPC associated with CAU 496, no sampling activities will take place.

However, QA/QC will be performed on the geophysical/radiological survey equipment and data to ensure the reliability of the survey results. 
SAFER PLAN - CAU 496

Section: QA/QC

Revision: 0

Date: May 2004

\section{THIS PAGE INTENTIONALLY LEFT BLANK}




\subsection{REFERENCES}

DOE/NV, see U.S. Department of Energy, Nevada Site Office.

EPA, see U.S. Environmental Protection Agency.

FFACO, see Federal Facility Agreement and Consent Order.

Federal Facility Agreement and Consent Order. 1996 (as amended). Agreed to by the State of Nevada, the U.S. Department of Energy, and the U.S. Department of Defense.

NNSA/NV, see U.S. Department of Energy, National Nuclear Security Administration Nevada Operation Office.

Nevada Division of Environmental Protection. 1999. Letter to Runore Wycoff, U.S. Department of Energy, Nevada Operations Office. Notice of Completion for Corrective Action Unit 495, Unconfirmed JTA Sites (TTR), July 14, Carson City, NV.

U.S. Department of Defense. 1999. DoD Ammunition and Explosives Safety Standards, DDESB 6055.9-STD.

U.S. Department of Energy, Nevada Operations Office. 2000. NV/YMP Radiological Control Manual, DOE/NV/11718-079, Revision 4, Las Vegas, Nevada.

U.S. Department of Energy, National Nuclear Security Administration Nevada Operations Office. 2002. Industrial Sites Quality Assurance Project Plan, Nevada Test Site, Nevada, DOE/NV--372, Revision 3. Las Vegas, NV.

U.S. Environmental Protection Agency. 2000. Guidance for the Data Quality Objectives Process, EPA QA/G-4, EPA/600/R-96-055. Washington, D.C.

U.S. Geological Survey. 1971. Geology of Northern Nellis Air Force Base Bombing and Gunnery Range, Nye County, Nevada. Prepared by E. B. Ekren, R. E. Anderson, C. L. Rogers, and D. C. Noble for the U.S. Atomic Energy Commission. Professional Paper 651. Washington, DC. 
SAFER PLAN - CAU 496

Section: Referenc es

Revision: 0

Date: May 2004

\section{THIS PAGE INTENTIONALLY LEFT BLANK}


SAFER PLAN - CAU 496

Section: Appendix A1

Revision: 0

Date: May 2004

APPENDIX A1

\section{DATA QUALITY OBJECTIVES}


SAFER PLAN - CAU 496

Section: Appendix A1

Revision: 0

Date: May 2004

\section{THIS PAGE INTENTIONALLY LEFT BLANK}




\section{ACRONYMS AND ABBREVIATIONS}

\begin{tabular}{|c|c|}
\hline $\mathrm{BN}$ & Bechtel Nevada \\
\hline CAI & Corrective Action Investigation \\
\hline CAS & Corrective Action Site \\
\hline CAU & Corrective Action Unit \\
\hline $\mathrm{COC}$ & Contaminant(s) of concern \\
\hline $\mathrm{COPC}$ & Contaminant(s) of potential concern \\
\hline CSM & Conceptual Site Model \\
\hline DOE & U.S. Department of Energy \\
\hline $\mathrm{DOE} / \mathrm{NV}$ & U.S. Department of Energy, Nevada Operations Office \\
\hline DQO & Data Quality Objective(s) \\
\hline DU & Depleted uranium \\
\hline EPA & U.S. Environmental Protection Agency \\
\hline FFACO & Federal Facility Agreement and Consent Order \\
\hline $\mathrm{ft}$ & foot (feet) \\
\hline $\mathrm{ft}^{2}$ & square feet \\
\hline $\mathrm{ft}^{3}$ & cubic feet \\
\hline IT & International Technology \\
\hline $\mathrm{m}$ & meter(s) \\
\hline $\mathrm{m}^{2}$ & square meters \\
\hline $\mathrm{m}^{3}$ & cubic meters \\
\hline \multirow[t]{2}{*}{ NNSA/NSO } & U.S. Department of Energy, National Nuclear Security Administration Nevada \\
\hline & Site Office \\
\hline NDEP & Nevada Division of Environmental Protection \\
\hline SAFER & Streamlined Approach for Environmental Restoration \\
\hline TTR & Tonopah Test Range \\
\hline UXO & Unexploded ordnance \\
\hline
\end{tabular}


SAFER PLAN - CAU 496

Section: A1

Revision: 0

Date: May 2004

THIS PAGE INTENTIONALLY LEFT BLANK 


\section{APPENDIX A1 \\ DATA QUALITY OBJECTIVES FOR \\ CORRECTIVE ACTION UNIT 496: BURIED ROCKET SITE, ANT ELOPE L AKE, TONOPAH TEST RANGE, NEVADA}

\section{Presentation of Known Data Related to Corrective Action Unit 496}

The information presented in this worksheet is based on historical data generated from preliminary assessment activities for Corrective Action Unit (CAU) 496 at the Tonopah Test Range (TTR). Data quality objective (DQO) worksheets follow the U.S. Environmental Protection Agency (EPA) DQO guidance outline (EPA, 2000). The steps systematically build on the data acquired during preliminary assessment work and background research. Copies of the preliminary assessment work are retained in the project files.

Members of the Planning Team:

1. U.S. Department of Energy, National Nuclear Security Agency Nevada Site Office $\underline{(\mathrm{NNSA} / \mathrm{NSO})}$

Janet Appenzeller-Wing

Kevin Cabble

2. Bechtel Nevada (BN)

Ronald Jackson

Reed Poderis

Dudley Emer

Kevin Campbell

3. Nevada Division of Environmental Protection (NDEP)

Clem Goewert

4. Core Decision Team

Janet Appenzeller-Wing (NNSA/NSO)

Kevin Cabble (NNSA/NSO)

Brad Jackson (BN)

5. $\quad$ Primary Decision Makers

Janet Appenzeller- Wing (NNSA/NSO)

Kevin Cabble (NNSA/NSO) 


\subsection{STATE THE PROBLEM (Step 1)}

Concisely describe the problem to be studied. Review prior studies and existing information to gain a sufficient understanding to define the problem.

The general nature of the CAU 496 CAS is understood, however additional information is needed to determine the location. Information will be used to close this site under the Streamlined Approach to Environmental Restoration (SAFER) process.

\subsection{CAS Specific Information}

CAU 496 is comprised of one Corrective Action Site (CAS) (FFACO, 1996):

- TA-55-008-TAAL, Buried Rocket.

The following sections describe the CAS included in CAU 496 and the conceptual site models that apply to the single CAS.

\subsubsection{CAS TA-55-008-TAAL, Buried Rocket}

CAS TA-55-008-TAAL, Buried Rocket, consists of a possible buried rocket or rocket parts from an unknown test. The CAS was designated based on one former employee's memory of a rocket that malfunctioned and fell on Antelope Lake in the 1960s. A general location for the rocket was obtained from the employee. There are numerous conflicting accounts regarding a missing rocket at TTR.

If a rocket was lost on Antelope Lake it may consist of an entire rocket that is buried at depth or it may have refracted up towards or onto the surface of the playa. The buried rocket site may have been confused with another similar site (CAS RG-52-007-TAML, Davis Gun Penetrator Test). There are no contaminants of potential concern (COPC) other than the rocket itself expected at this site. There is no information suggesting that any COPC might be associated with the site.

\subsection{Develop/Refine The Conceptual Site Model}

The primary and secondary conceptual site models (CSMs) are based on information derived from site process knowledge, historical background information, site analysis, and personnel interviews relative to the activities related to the CAS. One primary CSM and two secondary CSMs have been developed for CAU 496. The primary and secondary CSMs are presented on the attached figure.

\subsubsection{Buried Rocket Primary Conceptual Site Model}

This CSM addresses areas where the rocket itself or system components have been released to the ground surface or may have penetrated the subsurface. The primary CSM assumes a steep angle of entry and potential deep penetration. If the rocket or components are located, they are expected to be present in the shallow subsurface and may be detected using geophysical methods.

\subsubsection{Buried Rocket Secondary Conceptual Site Models}

The secondary CSMs developed for CAU 496 involve a shallow entry angle for the rocket. In these models the rocket could have penetrated the ground surface at a shallow angle and may 
have traveled horizontally at a relatively shallow depth, or the rocket could have refracted within the subsurface and traveled back toward and possibly reaching the ground surface. An alternate to the secondary CSMs include the rocket being located in an area outside of Antelope Lake.

The conditions under the secondary CSMs for CAU 496 are considered less likely than the conditions for the primary CSM. No information has been identified that suggests conditions outside the primary CSM are present. The secondary CSMs for CAU 496 are similar to the primary model with one or more of the following exceptions:

- Potentially buried rocket and/or associated debris may be deeper than anticipated. This poses a situation where site conditions may exceed the technical limitations of available geophysical methods.

- Debris associated with CAU 496 is not located within the survey areas or the event did not actually happen.

- $\quad$ Surface debris expected to be non-impacted are determined to be impacted.

- $\quad$ Areas with suspected surface debris are determined to extend into the subsurface.

- A corrective action site can not be located due to unavailability of information, technology limitations, or other causes. Closure of the site will proceed following the precedent established by CAU 495 (Unconfirmed Joint Test Assembly Sites) where the site was promoted to FFACO Appendix IV with the caveat that the site would be reopened for investigation if additional information was found in the future (Nevada Division of Environmental Protection [NDEP], 1999).

\subsection{Potential Hold Points}

During closure activities, certain conditions affecting the project schedule and budget may require decisions prior to continuing work. Primary hold points during the CAU 496 SAFER process have been identified and include the review of data for the selection of potential site locations for further investigation.

The results of geophysical and radiological surveys will be reviewed and presented to the NNSA/NSO and/or the NDEP. Three potential results are possible and will be evaluated for further action. The potential results include the following: the buried rocket and/or fragments of the rocket are located in the subsurface, the rocket or fragments of the rocket are located on the ground surface in an area off of Antelope Lake, or the rocket can not be located because it does not exist or it is buried at a depth that exceeds instrument capabilities. If multiple potential targets are identified, a decision will be made concerning which targets are to be investigated and the nature of investigation required. In the event that no targets or potential targets are identified for a specific site the alternative CSM will be evaluated for additional areas of investigation or closure by no further action using the CAU 495 (Unconfirmed Joint Test Assembly Sites) scenario (caveat that the CAU may be closed but will be reopened if additional information is found in the future) (NDEP, 1999).

An additional hold/decision point occurs during the investigation when results of air sampling for beryllium and soil DU screening results will be reviewed with the NNSA and/or the NDEP to confirm the cleanup and/or closure approach. Throughout the investigation/closure process, data will be collected, evaluated, and presented to NNSA for review and input. 
In addition to the previously discussed hold/decision points, work may be temporarily suspended until the issue can be satisfactorily resolved if any of the following unexpected conditions occur:

- $\quad$ Conditions outside the scope of work are encountered such as large amounts of unexploded ordnance,

- Radiological screening yields results which require an upgrade in procedures to continue survey work in specific areas,

- $\quad$ Elevated beryllium results for air samples collected in the worker breathing zone,

- $\quad$ Elevated levels of additional COPC not originally identified as being present at the sites

- Unexpected conditions including waste and/or contamination,

- Out-of-scope work activities such as the detection of other contaminants of concern (COC) that would require re-evaluating a disposal pathway, such as with hazardous or low level waste,

- Unsafe conditions or work practices posing a threat to personnel, equipment, or the environment, not originally documented in the Site Specific Health and Safety Plan,

- Other technical factors requiring the preparation of a Record of Technical Change to the approved SAFER Plan.

\subsection{IDENTIFY THE DECISION (Step 2)}

Identify what questions the study will attempt to resolve, and what actions may result.

Development of a SAFER Plan will be prepared based on the currently available process knowledge, historical information, and geophysical data. The CAS within CAU 496 is a site where the location has not been confirmed.

For CAU 496 where the location has not been confirmed, historical information, interviews, site conditions, and radiological geophysical data will be evaluated and a potential target location will be identified, if possible. Potential target information will be presented to NNSA/NSO for concurrence and documentation. Selected targets will be addressed during the Corrective Action Investigation (CAI). Findings of the CAI will be evaluated with NNSA/NSO and the corrective action approach will be confirmed and documented. If the rocket is located, it will be removed if feasible. If the rocket is located but is too deep and not technically feasible to remove, the site may be closed in place.

If the rocket can not be located the approach previously approved by NDEP for CAS 495 (Unconfirmed Joint Test Assembly Sites) will be implemented (NDEP, 1999). This approach will allow closure of the unconfirmed site with no land/site use restrictions and no post-closure monitoring. However, should additional evidence become available in the future which indicates the location of the site, the site should be reopened to continue the investigation.

\subsection{IDENTIFY THE INPUTS TO THE DECISION (Step 3)}

This step identifies the information needed and sources of information, the basis for establishing action levels, and sampling and analysis methods that can meet the data requirements.

\subsection{Identify the Information Inputs Needed and Resolve the Decision}

The northern half of Antelope Lake will be surveyed using geophysical methods to locate buried 
metallic objects. In addition, areas surrounding the lake will be visually inspected for rocket debris potentially related to the CAS.

\subsection{List Types of Contaminants of Potential Concern and Affected Media}

As the actual components of the alleged buried rocket are unknown no COPC are expected to be encountered.

\subsection{Identify Potential Sampling Approaches and Appropriate Analytical Methods} The following will be used to resolve the decision rules and confirm the nature and extent of waste for each CAS:

\section{- Geophysical Surveys}

Electromagnetic surveys will be used to determine the presence and lateral extent of areas containing surface or near-surface metallic objects/particles. Geophysical surveys will follow standard procedures. Additional geophysical methods may be used as needed to better refine the CAS boundaries and/or location.

\subsection{DEFINE THE STUDY BOUNDARIES (Step 4)}

Specify the time periods and spatial area to which decisions will apply. Determine when and where data should be collected. The purpose of this step is to define the target population of interest, specify the spatial and temporal features of that population that are pertinent for decision making, determine practical constraints on data collection, and define the scale of decision making relevant to target populations for Decision I and Decision II.

\subsection{Define the Geographic Areas of the Field Investigation}

\subsubsection{Define the Geographic Area Within Which All Decisions Must Apply}

CAU 496 has been defined based on the historical data collected during previous investigations. The area of the surveys performed for CAU 484 SAFER activities will also cover the approximate location of the buried rocket as indicated by a former TTR employee.

\subsubsection{Specify the Characteristics That Define the Population of Interest}

The population of interest is an area on the northeast portion of Antelope Lake. The debris may include material found on the surface or buried near-surface that may be related to the account of the buried rocket.

\subsection{Define the Time Frame of the Decision}

The time frame of the decision will be based on the results of analysis of the aerial, geophysical, and radiological surveys. If a suspected target is located then a decision will be made as to how to best investigate the target.

\subsubsection{Determine the Time Frame to Which the Study Data Apply}

The study data should be relevant with the length of time allowed for by the SAFER process under the FFACO agreement. The decisions will be based on the documentation and data collection activities planned for 2004 and combined with the planned surveys to determine the proper recommendations for the CAS. 


\subsubsection{Determine When to Collect Data}

Field activities (data collection) are scheduled to take place in fiscal year 2004 and closure activities will be completed after approval of the final SAFER Plan. Data will be collected at times that meet the security and safety constraints of the TTR site, and at times when weather conditions that allow adequate site access and safe working conditions.

\subsubsection{Define Relevant Time Constraints}

- $\quad$ The final SAFER Plan is due to the U.S. Department of Energy, National Nuclear Security Agency Nevada Site Office by May 3, 2004.

- $\quad$ The FFACO deadline for the SAFER Plan is September 30, 2004.

- $\quad$ Fieldwork will be tentatively scheduled to begin during fiscal year 2005.

\subsection{Identify Any Practical Constraints on Data Collection}

1. Approval of the SAFER Plan and the DQO process by the NDEP.

2. Equipment access and mobility at the TTR.

3. Meteorological events that may impact fieldwork activities.

4. Health and safety of workers.

5. Operational/Security issues at the TTR.

6. Unforeseen conditions including UXO and other unsafe working conditions.

\subsection{DEVELOP A DECISION RULE (Step 5)}

Define the parameter of interest, specify the action level, and integrate the previous DQO inputs into a single statement that describes the logical basis for choosing among alternative actions. This step integrates outputs from the previous steps, with the inputs developed in this step into a decision rule ('If..., then...") statement. This decision rule describes the conditions under which possible alternative actions would be chosen.

\subsection{Decision Rule}

The parameter of interest for CAU 496 is the presence or absence of the buried rocket.

Decision I - If potential targets are identified based on visual inspections, geophysical surveys, and it is technically feasible, then the site will be clean closed.

Decision II - If potential targets are identified based on visual inspections, geophysical surveys, but are buried deeper than $3 \mathrm{~m} \mathrm{(10} \mathrm{ft)} \mathrm{below} \mathrm{ground} \mathrm{surface,} \mathrm{then} \mathrm{the} \mathrm{site} \mathrm{will} \mathrm{be} \mathrm{closed} \mathrm{in} \mathrm{place}$ and use restrictions implemented.

Decision III - If no potential targets are identified that could possibly be related to this CAS, then the site will be closed by tanking no further action using the approach previously approved by NDEP for CAS 495 (NDEP, 1999). (This approach will allow closure of the unconfirmed site with no use restrictions and no post-closure monitoring. However, if additional evidence becomes available in the future which indicates the location of the site, the site will be reopened to continue the investigation.) 


\subsection{Specify the Action Level or Preliminary Action Level for the Decision}

The determination of whether or not the buried rocket is present will be made by visual observations of surface debris, and the results of geophysical surveys. Survey data will be examined and interpreted by subject mater experts for any indication of the presence of the buried rocket. No COC are expected at this site. If any conditions outside the scope of work are observed, then work will stop until an appropriate change of scope is approved.

\subsection{SPECIFY TOLERABLE LIMITS ON DECISION ERRORS (Step 6)}

Define the decision makers tolerable decision error rates based on a consideration of the consequences of making an incorrect decision.

\subsection{Decision Errors}

Only valid data generated from the geophysical and radiological surveys will be used to determine if the buried rocket is present, and if present, its location. The null hypothesis is that the buried rocket, the waste, is present. The types of decision errors include:

- $\quad$ False Negative (rejection of the null hypothesis) Decision Error which would mean waste is determined not to be present when it actually is present.

- $\quad$ False Positive (acceptance of the null hypothesis) Decision Error which would mean that waste is determined to be present when it is actually not present.

\subsubsection{False Negative Decision Error}

The false negative decision error would mean waste is determined not to be present when it actually is present. A false negative decision error is controlled by meeting the following criteria:

- $\quad$ Having a high degree of confidence that the area to be surveyed is the most likely area for the buried rocket to be located.

- Having a high degree of confidence that the survey data generated is of acceptable quality to identify the presence or absence of the buried rocket.

To satisfy the first criteria the area surveyed is that identified in the CAU 496 preliminary assessment. Also, this area is contained within a larger area that will be surveyed as part of the CAU 484 closure activities.

To satisfy the second criteria all survey data will be reduced, examined, and interpreted by inhouse geophysical and radiological subject matter experts.

\subsubsection{False Positive Decision Error}

A false positive decision error would mean that waste is determined to be present when it is actually not present. A false positive decision error is controlled by protecting against false positive survey results; results that indicate that the buried rocket is present when it is not. False positive results are typically attributed to bad survey data generated by malfunctioning or improperly calibrated instruments. To minimize the risk of a false positive decision error all 
survey instruments will be periodically calibrated and tested to ensure that they are in proper working condition and that the data being generated is usable. Any instrument that is found to be not functioning within acc eptable tolerance limits will be removed from service and, if nec essary, the effected area resurveyed to generate usable data.

\subsection{OPTIMIZE THE DESIGN (Step 7)}

Evaluate information from the previous steps and generate alternative data collection designs. Choose the most resource-effective design that meets all DQOs. This section presents an overview of the resource-effective strategy planned to obtain the data required to meet the project DQOs developed in previous steps. As additional data or information is obtained, this step will be reevaluated and refined, if necessary, to reduce uncertainty and increase the confidence that the SAFER CAI has met its intended goals.

\subsection{Develop General Sampling and Analysis Design Alternatives}

If a target area for the site location is identified, any material removed from the site will be screened for radioactivity above free release criteria. The work area will be continuously visually inspected for staining indicating the presence of COPC and/or areas of environmental impact. As there are no presumed COPC related to the site, sampling will not be performed unless field observations indicate potential COC impact of the surrounding material.

\subsection{CAU 496 Closure Decision Process}

Hold/decision points have been included in the process to allow critical data to be reviewed by the parties prior to proceeding with the closure activities. A primary hold point for the CAU 496 closure activities will be the review of geophysical and radiological survey data and the selection of locations repres enting sites belonging to CAU 496. Due to the broadness of the initial surveys and the historical activities that have been conducted on the dry lake beds at TTR, there is a potential for identifying sites containing waste and/or contamination that are not associated with CAU 496. Only sites determined to be associated with CAU 496 will be addressed within the corrective actions described in these data quality objectives. 


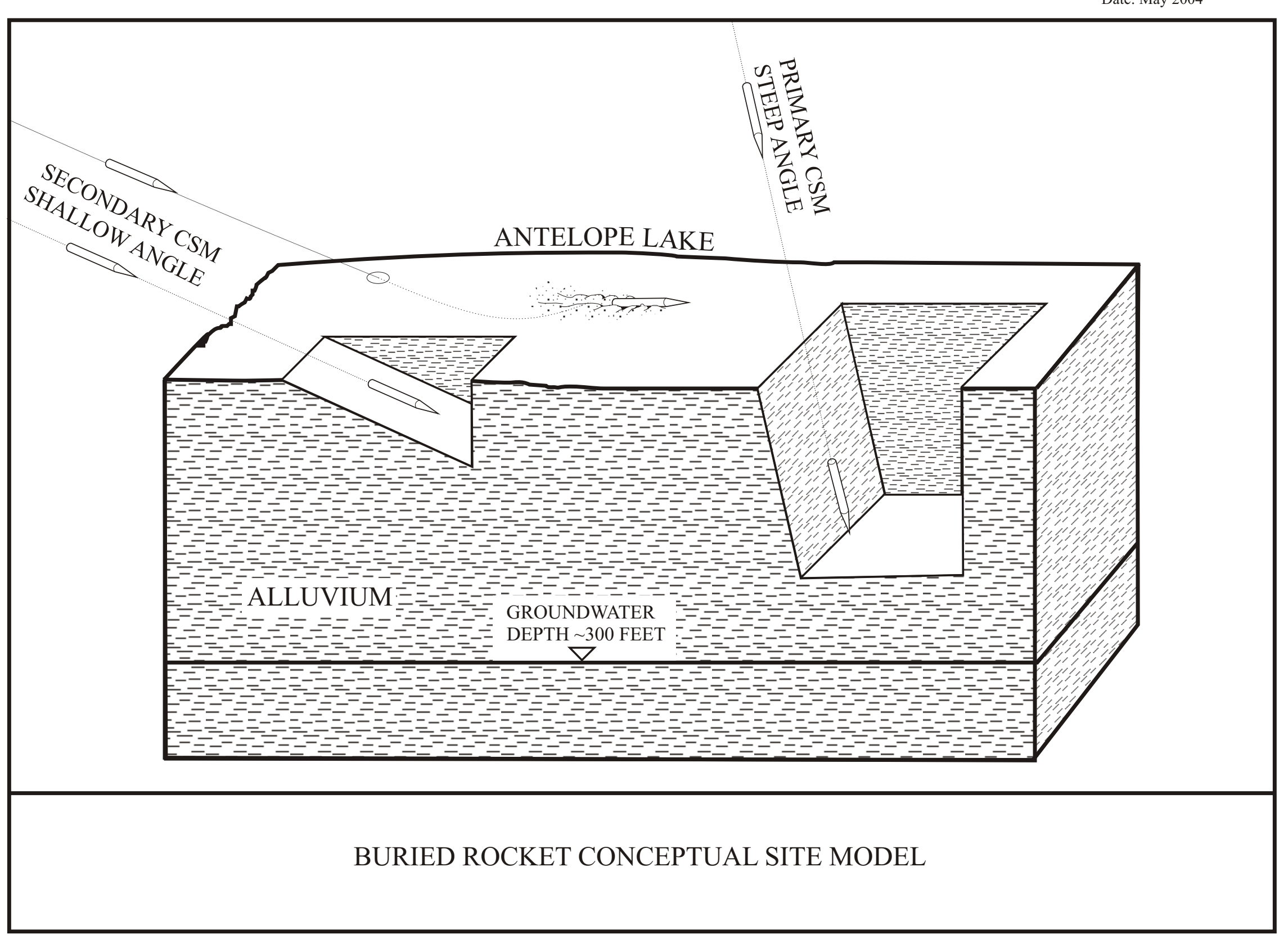




\section{REFERENCES}

FFACO, see Federal Agreement and Consent Order.

Federal Facility Agreement and Consent Order. 1996 (as amended). Agreed by the State of Nevada, the U.S. Department of Energy, and the U.S. Department of Defense.

NDEP, see Nevada Division of Environmental Protection.

Nevada Division of Environmental Protection. 1999. Letter to Runore Wycoff, U.S. Department of Energy Nevada Operations Office. Notice of Completion for Corrective Action Unit 495, Unconfirmed Joint Test Assembly (JTA) Sites, TTR. July 14. Carson City, NV.

U.S. Environmental Protection Agency. 2000. Guidance for the Data Quality Objectives Process, EPA QA/G-4, Washington, D.C. 
SAFER PLAN - CAU 496

Section: Appendix A2

Revision: 0

Date: May 2004

\section{APPENDIX A2}

PROJECT ORGANIZATION 
SAFER PLAN - CAU 496

Section: Appendix A2

Revision: 0

Date: May 2004

\section{THIS PAGE INTENTIONALLY LEFT BLANK}


The U.S. Department of Energy (DOE), National Nuclear Security Administration Nevada Site Office (NNSA/NSO) Project Manager or Task Manager will serve as the primary point of contact for all activities conducted in this project. The NNSA/NSO Project Manager is responsible for seeing that all activities conducted during the project fulfill the obligations of NNSA/NSO as described in the Federal Facility Agreement and Consent Order (FFACO) of 1996 and the Nevada Division of Environmental Protection (NDEP) approved work plan. The NNSA/NSO Project Manager will plan, authorize, and control project work so that activities are completed in accordance with the work plan on schedule and within budget. The NNSA/NSO Project Manager will be the primary point of contact with the NDEP. The NNSA/NSO points of contact for this project are as follows:

Acting Project Manager: Kevin Cabble

Telephone Number: (702) 295-5000

Task Manager: Kevin Cabble

Telephone Number: (702) 295-5000

The identification of the project Health and Safety Officer and the Quality Assurance Officer can be found in both the Field Management Plan and the Site-Specific Health and Safety Plan. However, personnel are subject to change and it is suggested that the appropriate NNSA/NSO Project Manager be contacted for further information. The Task Manager will be identified in the FFACO Monthly Activity Report prior to the start of field activities. 
SAFER PLAN - CAU 496

Section: Appendix A2

Revision: 0

Date: May 2004

\section{THIS PAGE INTENTIONALLY LEFT BLANK}


SAFER PLAN - CAU 496

Section: Distribution List

Revision: 0

Date: May 2004

\section{DISTRIBUTION LIST}


SAFER PLAN - CAU 496

Section: Distribution List

Revision: 0

Date: May 2004

\section{THIS PAGE INTENTIONALLY LEFT BLANK}


*Distribute only NDEP-approved revisions; others receive all revisions.

\section{$\underline{\text { Nevada Department of Environmental Protection }}$}

Ms. Terre A. Maize, Chief

1 (Controlled)

Bureau of Federal Facilities

Division of Environmental Protection

1771 East Flamingo Road, Suite 121-A

Las Vegas, NV 89119-0837

Bureau of Federal Facilities

1 (Controlled)

Division of Environmental Protection

333 W. Nye Lane, Room 138

Carson City, NV 89706-0851

Donald Elle

Bureau of Federal Facilities

Division of Environmental Protection

1771 East Flamingo Road, Suite 121-A

Las Vegas, NV 89119-0837

\section{U.S. Department of Energy}

Shirley Doty

1 (Controlled)

Environmental Restoration Division

U.S. Department of Energy

National Nuclear Security Administration Nevada Site Office

P.O. Box 98518, M/S 505

Las Vegas, NV 89193-8518

Kevin Cabble

1 (Uncontrolled)

Environmental Restoration Division

U.S. Department of Energy

National Nuclear Security Administration Nevada Site Office

P.O. Box 98518, M/S 505

Las Vegas, NV 89193-8518

Janet Appenzeller-Wing

1 (Uncontrolled)

Environmental Restoration Division

U.S. Department of Energy

National Nuclear Security Administration Nevada Site Office

P.O. Box 98518, M/S 505

Las Vegas, NV 89193-8518 


\section{DISTRIBUTION LIST (continued)}

*Distribute only NDEP-approved revisions; others receive all revisions.

\section{U.S. Department of Energy (continued)}

Southern Nevada Public Reading Facility

c/o Nuclear Testing Archive

P.O. Box 98521, M/S 400

Las Vegas, NV 89193-8521

U.S. Department of Energy

National Nuclear Security Administration Nevada Site Office

Technical Library

P.O. Box $98518, \mathrm{M} / \mathrm{S} 505$

Las Vegas, NV 89193-8518

U.S. Department of Energy

Office of Scientific and Technical Information

P.O. Box 62

Oak Ridge, TN 37831-0062

\section{Bechtel Nevada}

Correspondence Control

1 (Uncontrolled)

Bechtel Nevada

P.O. Box 98521, M/S NLV008

Las Vegas, NV 89193-8521

Kevin Campbell

1 (Uncontrolled)

Bechtel Nevada

P.O. Box 98521, M/S NTS306

Las Vegas, NV 89193-8521

Brad Jackson

Bechtel Nevada

P.O. Box 98521, M/S NTS306

Las Vegas, NV

David Madsen

Bechtel Nevada

P.O. Box 98521, M/S NTS306

Las Vegas, NV 89193-8521
1 (Controlled)* \&

1 (Uncontrolled)*

1 (Uncontrolled)* 


\title{
DISTRIBUTION LIST (continued)
}

*Distribute only NDEP-approved revisions; others receive all revisions.

Nye County

David Swanson

Assistant Project Administrator

1 (Uncontrolled) \&

Nye County

Department of Natural Resources and Federal Facilities

1210 E. Basin Road, Suite 6

Pahrump, NV 89060

\section{Stoller-Navarro Joint Venture}

Public Reading Room Coordinator

1 (Controlled)*

Stoller-Navarro Joint Venture

\author{
1 (Uncontrolled Electronic)*
}

7710 W. Cheyenne Ave., Bldg. 3

Las Vegas, NV 89129

Brian Hoenes

1 (Uncontrolled)

Stoller-Navarro Joint Venture

7710 W. Cheyenne Ave., Bldg. 3

Las Vegas, NV 89129

\section{State of Nevada}

Manager, Northern Nevada FFACO

1 (Uncontrolled)*

Public Reading Facility

c/o Nevada State Library and Archives

100 North Stewart Street

Carson City, NV 89701-4285

\section{U.S. Air Force}

E. V. Hopper

3 (Uncontrolled)

U.S. Air Force

99ABW-EM

4349 Duffer Drive, Suite 1601

Nellis AFB, NV 89191-7007

U.S. Air Force

1 (Uncontrolled)

98th Range Wing, XPL

Nellis AFB, NV 89191-7007

V. G. Gabbard

1 (Uncontrolled)

Sandia National Laboratory/TTR

Box 871

Tonopah, NV 89049 
*Distribute only NDEP-approved revisions; others receive all revisions.

\section{U.S. Air Force (continued)}

U.S. Air Force

1 uncontrolled

DOE Liaison Office

P.O. Box 98518, M/S 505

Las Vegas, NV 89193-8518

\section{Westinghouse Corp.}

Jerry Elliston

1 uncontrolled

Westinghouse

P.O. Box 528

Tonopah, NV 89049 